\title{
ENCOURAGING STUDENTS TO DO COLLABORATIVE LEARNING IN ESP COURSE TO STRENGTHEN STUDENTS' ORAL COMMUNICATION SKILL
}

\author{
Lia Agustina
}

State Polytechnic of Malang, Indonesia

Corresponding Author Email: lia_alfan2d@yahoo.com

\begin{tabular}{|c|c|}
\hline Article Info & Abstract \\
\hline $\begin{array}{l}\text { Article History } \\
\text { Received: October } 2021 \\
\text { Revised: } \\
\text { Published: }\end{array}$ & $\begin{array}{l}\text { Collaborative learning is a strategy of teaching and learning by grouping } \\
\text { students to work together to solve a problem, complete an assignment, and } \\
\text { produce a product. It increases learners' motivation and promotes a harmonious } \\
\text { atmosphere, decreasing classroom anxiety and facilitating interaction discussion }\end{array}$ \\
\hline $\begin{array}{l}\text { Keywords } \\
\text { Collaborative Learning; } \\
\text { Communication Skill; }\end{array}$ & $\begin{array}{l}\text { and an individual sense of self-centeredness. At the same time, it enlarges } \\
\text { students' knowledge and skills. One of the important skills is oral communication. } \\
\text { Oral communication is an important skill to learn as it could express ideas and } \\
\text { opinions. It uses to discuss knowledge and bridge the communication for ones } \\
\text { who do not understand English. Therefore, this study aims to encourage students } \\
\text { to do collaborative learning to strengthen their oral communication skills. The } \\
\text { researcher used the action research method to see the improvement of the } \\
\text { students' communication skills. The subject was } 32 \text { students of the Accounting } \\
\text { Department State Polytechnic of Malang. The study resulted that most students } \\
\text { showed an improvement in all four language skills, but speaking skills had the } \\
\text { greatest improvement. }\end{array}$ \\
\hline
\end{tabular}

How to cite: $(2022)$. Encouraging students to do collaborative learning in ESP course to strengthen students' oral communication skill, JOLLT Journal of Languages and Language Teaching, 10(1), pp. 76-84. DOI: https://doi.org/10.33394/jollt.v\%vi\%i.4353

\section{INTRODUCTION}

Mostly, teachers focused their teaching activities on fulfilling their target in teaching and learning process based on the curriculum (Anwar et al., 2021). They feel comfortable delivering their materials from curriculum in time without thinking about the growth of their students either physically or mentally. Teachers are happy if their students pay attention to the lesson quietly, work on the assignment, and do not talk (Fernandez-Dobao, 2020; Khonamri et al., 2021). Teachers have lectured, and students have listened. The educationally talented students might not demonstrate their capability in the classroom. When teaching is presented in a classroom, some students have no chance to reach beyond the level provided. If grades and competition do not encourage the students, they may be glad to coast along in the classroom. These students may experience a categorical lack of motivation (Van de Guchte et al., 2019), lack of participation (Abe, 2013), and outward disinterest (Suparlan, 2021).

While in fact, oral communication could be a vital skill to be learnt since it has specific conceptions and opinions (Abe, 2013; Uztosun, 2020). It is used to talk about knowledge and bridge the communication for those who have problems in English. Researchers have examined the model of Collaborative Learning for over two decades. It has been as a strategic learning model. The utilization of the collaborative learning model has been completely enforced inside the classroom and students advantage academically and socially when working in a group to accomplish the goal. Ushioda (2003) states that collaborative learning increases learners' motivation and promotes harmonious group 
dynamics, lowering classroom anxiety and facilitating interaction in the classroom as well as an individual sense of self-competence and self-worth.

In contrast to individual learning, students who participate in collaborative learning appreciate on other's resources and skills, discuss data founded, assess ideas, and observe each other's work. These activities help them work together in any part of learning activities to speak in classes (Heinimaki et al., 2021; Carvalho \& Santos, 2021). More specifically, collaborative learning is fundamentally founded on the model that knowledge is frequently created within a group by sharing experiences (Deng et al., 2021). Collaborative learning refers to methodologies and environments in that students rely upon in their task wherever each individual depends on and is responsible to every different (Munoz et al., 2021). These include personal discussions.

In the collaborative learning environment, the learners are challenged both socially and emotionally as they listen to different perspectives and must articulate and defend their ideas. In so doing, the learners begin to create their own unique conceptual frameworks and not rely solely on an expert's or a text's framework (Li et al., 2021). Thus, in a collaborative learning setting, learners have the opportunity to converse with peers, present and defend ideas, exchange diverse beliefs, question other conceptual frameworks, and be actively engaged.

This study was directed to see the effective feedback obtained from encouraging students to do collaborative learning in ESP Course to strengthen students' Oral Communication, and it was conducted under the following assumptions. First, it was assumed that encouraging students to do collaborative learning in ESP Course to strengthen students' Oral Communication skill was a crucial tool to improve students' learning and achievement. Second, conducting Collaborative Learning in implementing a business meeting project would motivate students' oral communication skills. In line with the idea of the study, the formulated research problem would be; "How could a Teacher Encourage Students Do Collaborative Learning In ESP Course Strengthen Students' Oral Communication Skill'?

\section{The Importance of Motivation}

Having a motivation is quite important in teaching and learning activity (Csizer \& Kormos, 2009; Bracken \& Lombard, 2004). It is the fundamental push to move someone to learn the course subject. It is an influence that can be from inside or outside that pushes someone to succeed a certain aim set before. Learning is a process of activity to change the behaviour of the learner (Henry \& Cliffordson, 2017). There are many factors that influence both internal or external factor of the learner. It is apparent that one problem that a teachera teacher faces to prepare out her teaching is how to motivate or increase the motivation to the learner effectively. The success in one teaching is influenced by motivator. Study is the learning process for students to build ideas, create plans, and comprehend them. So the learning activities would give a chance to do their learning process simply, enjoy and motivate. So the atmosphere created by the teacher would involve learners actively, such as observe, analyze, ask, explained, discuss, and some kinds of involving form.

\section{Collaborative Learning}

The teacher's center teaching strategy has been accepted for years, but it is setting to lose ground. As Educators starting to notice the value of Collaborative Learning techniques, and the strategy is becoming popular in today's when students come together in groups, it advises a way of dealing with other students that respect and highlights every member's abilities, ideas and contributions. There is a tolerance of either authority and acceptance of responsibility among group members for the group's actions. Collaborative learning is a strategy that refers to an activity to improve or make better in terms of quality, worth, or value 
(Sheth et al., 2020; den Hertog \& Elstak, 2020). It could be in the performance of ideas, objects or processes that more attractive by adding or removing components that can rouse students to participate during the process of learning English. Collaborative learning is needed in accomplishing critical thinking (Cullen et al., 2013).

According to Gokhale (1995), individuals are able to achieve higher levels of learning and retain more information when they work in a group rather than individually, this applies to both the facilitators of knowledge, the instructors, the receivers of knowledge, and the students. The benefits of collaborative learning include improving students' higher-level thinking, speaking practice, self-management, and leadership skills; encouraging students' interaction; increasing student retention, confidence, and responsibility; increasing the understanding of different points of view; and prreparing for future life and employment atmosphere. The concept of Collaborative Learning, the grouping and pairing of learners to achieve a learning goal, has been widely researched and advocated; the term of Collaborative Learning refers to an instruction method in which learners at various performance levels work together in small groups toward a goal. The learners are responsible for one to another learning as well as their own. Thus, the success of one learner helps other students to be successful (Gokhale, A.A., 1995). Numerous benefits have been described for Collaborative Learning (Pantiz, T., 1999). A good way for organizing the benefits of Collaborative Learning, are to put them in categories. list over 50 benefits for CL. The list below is based on their works. This paper summarizes them into four major categories of; social, psychological, academic and assessment, as in following:

In the context of social benefits, collaborative learning helps to develop a social support system for learners (Johnsons, 1989; Pantiz, 1999). Collaborative learning leads to build diversity understanding among students and staff. In the academic context, collaborative learning involves students actively in the learning process. Therefore, classroom results are improved (Cullen et al., 2013). Collaborative learning is especially helpful in motivating students in specific curriculum. It also alternate student and teacher assessment techniques. Collaborative learning establishes a positive atmosphere for modelling and practicing cooperation, and; collaborative learning develops learning communities (Taguchi \& Kim, 2016).

\section{METHOD}

\section{Research Design}

This research employed qualitative research design. Lewin (in Kemmis and Taggart 1992) described action research as proceeding in a spiral of steps, each of which was composed of planning, action and the evaluation of the result of the action. Kemmis and Taggart (1992) defined planning as constructed action and by definition must be prospective to action-it must be forward looking. It must be recognized that all social action was to some degree unpredictable and therefore somewhat risky. The general plan must be flexible enough to adapt to unforeseen effects and previously unrecognized constraints. While the action was deliberate and controlled-it was a careful and thoughtful variation of practice and was critically informed. Furthermore, they mentioned that observation had the function of documenting the effects of critically informed action and reflection recalls action as it had been recorded in observation, but it was also active. The last step in a circle was reflection. research spiral of planning, action, observing and reflecting. The data was analyzed descriptively to describe students' perception of the teaching methodology. 


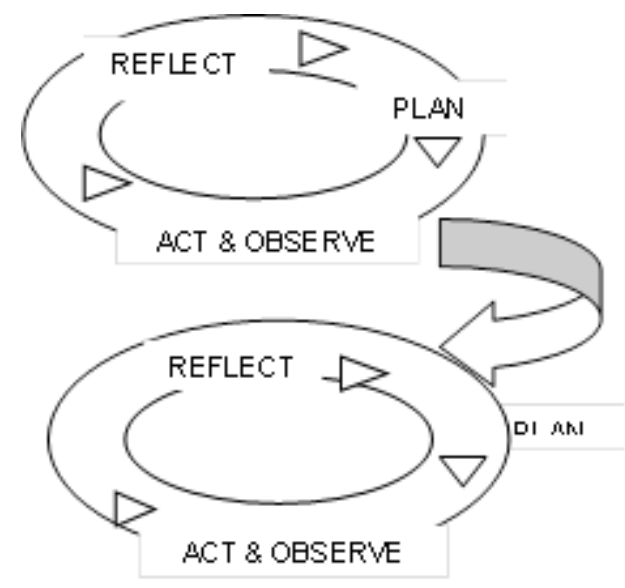

Figure. 1 Classroom Action Research Design (Kemmis \& Taggart, 1992)

\section{Research Subjects}

The subject of the study was the Accounting students of the third semester of D3 Program, State Polytechnic of Malang. The subject was 32 students involved in this study. The selection of the research subject considers the particularity and possibility to carry out the classroom action research. The particularity of the subject considers that the third semester students have the average ability of speaking skills. because of this, it has possibility to see the improvement of speaking skills or communication skills in the current study.

\section{Research Instruments}

Pre Test and Post Test

Pretest and Post test was used to measure the knowledge attained in the classroom with diverse learning styles and educational backgrounds. More specifically, the tests indicated how the students were learning in the class. The data target students requiring extra help and identified teaching and learning methods that needed to be changed or developed.

Pretest used to measure a starting point or the amount of pre-exist knowledge they studied before, to indicate to the student the learning in their level. Post test used to measure the learning as a result of the course experience and to target any instructional needs to improve the learning.

\section{Questionnaire}

A questionnaire was a number of writer questions which were used to gain information from respondents about their knowledge, beliefs etc. The questionnaire was used to measure the students and the English teacher the problems in English teaching learning process and to know their motivation of it.

\section{Observation}

Observation was used in order to watch the process of the strategy implemented by direct observation. The writer provided the Observation List used as the instrument for collecting the data and the Proficiency Description for the Criteria. Those were provided for grouping the information of the students ${ }^{\text {ee }}$ activities. There were students' significant improvements, The indicator of observing students ${ }^{\text {ee }}$ activeness in collaborative learning activity in group were; (a) students participated actively involved in the project assigned, (b) students worked and discussed together in a group, (c) students appreciated every member in 
a group, (d) students helped and tolerated their friends in the group, (e) students created individual responsibility, (f) Students increased the skills and the knowledge together, $(\mathrm{g})$ students faced the problems and solved the problems together, and (h) group management was working well. Meanwhile, the indicators use criteria seen in Table 1:

Table 1.

Students score's Interval

\begin{tabular}{ll}
\hline $85-100$ & Excellent \\
\hline $71-84$ & Very good \\
\hline $60-70$ & Good \\
\hline $40-59$ & Low \\
\hline $0-39$ & Failed \\
\hline
\end{tabular}

\section{RESULTS AND DISCUSSIONS}

In the traditional methods, students tend to participate in non-interactively receive the materials from a teacher. While collaborative learning is a strategy of teaching and learning, students' team together, discuss, create, and produce a significant project. Some researchers stated about the students' academic achievement and retention by comparing a group working and individual working. The result found that students working in groups considerably have significant achievement and retention.

Table 2

Students' Learning Processes of the Speaking Class

\begin{tabular}{|c|c|c|c|}
\hline No & Activities & $\begin{array}{l}\text { The Action Result } \\
\text { of a Researcher/a Teacher }\end{array}$ & $\begin{array}{l}\text { The Action Result } \\
\text { Of Students }\end{array}$ \\
\hline 1 & $\begin{array}{l}\text { Pre Test } \\
\text { Atmosphere }\end{array}$ & $\begin{array}{l}\text { The researcher had a good motivation } \\
\text { when teaching but she tended to } \\
\text { dominate the class }\end{array}$ & $\begin{array}{l}\text { The students were passive, tended only } \\
\text { listened and worked the exercises alone. }\end{array}$ \\
\hline 2 & $\begin{array}{l}\text { Collaborative } \\
\text { Learning }\end{array}$ & $\begin{array}{l}\text { The researcher implemented the strategy, } \\
\text { explained the project assigned and } \\
\text { informed the steps used in completing } \\
\text { the assignment }\end{array}$ & $\begin{array}{l}\text { Confuse but tried to adapt the strategy } \\
\text { implemented }\end{array}$ \\
\hline 3 & Learning & $\begin{array}{l}\text { During the process of implementing the } \\
\text { strategy, the domination of the teacher } \\
\text { was decreased }\end{array}$ & $\begin{array}{l}\text { The active students were still dominated in } \\
\text { the discussion to finish the project }\end{array}$ \\
\hline 4 & Learning & $\begin{array}{l}\text { The teacher handle the class by coming } \\
\text { to each group and did the discussion of } \\
\text { the project assigned }\end{array}$ & $\begin{array}{l}\text { All Students already adapted the CL } \\
\text { atmosphere and felt motivated in working the } \\
\text { project }\end{array}$ \\
\hline 5 & Learning & $\begin{array}{l}\text { The researcher received the consultation } \\
\text { Every group came to the researcher in } \\
\text { turn and did the consultation }\end{array}$ & $\begin{array}{l}\text { Students having a good interaction among } \\
\text { them } \\
\text { Every single student had own responsible and } \\
\text { help each other to complete the assignment }\end{array}$ \\
\hline 6 & $\begin{array}{l}\text { Result of the } \\
\text { Collaborative } \\
\text { Learning }\end{array}$ & $\begin{array}{l}\text { The researcher received the consultation } \\
\text { Every group came to the researcher in } \\
\text { turn and did the consultation }\end{array}$ & $\begin{array}{l}\text { Students did actively, creative and innovative, } \\
\text { Students' high motivation could be read well } \\
\text { Students aware of working best on the } \\
\text { assignments }\end{array}$ \\
\hline
\end{tabular}

By assigning a project to the students in which the students have to find out the solution of the complex problems met in the ESP Course implemented, the researcher realized that the 
students' high of level thinking was developed well. It was also happened when students assigned to draw upon their past experience and knowledge. Students became actively participating and developed their oral communication, even students could manage their management by themselves to complete the assigned project, and their leadership skill immediately appeared. Collaborative learning promotes student-students and student-teacher interaction. Because of the interaction created, then the students' retention, self-esteem and responsibility were also increased. The exposure increased the understanding of numerous perspectives. It was very helpful to arrange for a social real-life and employment situations. The assigned project was interesting and challenged the students to complete it.

When completing the project, the students learned skills for resolving conflicts and it were; developed the skill of the technology facing, developed the skill of solving problems, when students; should combine ideas, should share assignments, should appreciate the atmosphere created, should create a tolerance, should manage time, should comprehend peer's group characters, should respect to every member of the team and should hear other ideas, developed the skills of language, developed the knowledge relate to the project's assigned by drawing their past experience and new knowledge, and students were really invested in their own learning.

Table 3

Students' Responses of Collaborative Learning

\begin{tabular}{ll}
\hline NO & QUESTIONS \\
\hline 1 & $\begin{array}{l}\text { Do you think the implementation of doing a collaborative learning enhance your language } \\
\text { learning }\end{array}$ \\
\hline 2 & $\begin{array}{l}\text { How do you feel with the project that should be implemented by using a collaborative } \\
\text { learning model (before and after the project) whether it is influenced on your language } \\
\text { learning or not }\end{array}$ \\
\hline 3 & Do you like the model to be implemented \\
\hline 4 & Do you agree that the model implemented will help you in the future life \\
\hline 6 & English is more interesting to be learnt when the atmosphere created is attracting \\
\hline 7 & $\begin{array}{l}\text { What is your opinion of learning English traditionally comparing to the model implemented, } \\
\text { is it enhanced your language learning. }\end{array}$ \\
\hline 8 & Do you get any additional knowledge by experiencing the model implemented \\
\hline 9 & Do you like the project implemented \\
\hline 10 & Collaborative Learning \\
\hline 11 & Dork in a group is not an easy job, tell your opinion \\
\hline 12 & Do your motivation increased when learning the model proposed \\
\hline 13 & Implement the collaborative learning is a good model, tell your opinion \\
\hline
\end{tabular}

Students realized that Collaborative learning strategy enhanced their language learning, self-confidence, skills, and knowledge. The knowledge was not only on English but also on other subjects that related to the assignments' content. Event the strategy already improved the students' characters such as tolerance, respect, appreciation and think of others. The strategy helped to every single student working in a group that prepared students' social life in the future (wang et al., 2021). In the learning activities, students are asked to work in a small group to see and analyze cases or problems. Students are pointed different roles in the group such as a leader, recorder, presenter, and advisor. Because of this, students can practice oral communication effectively (Dong et al., 2021).

Before the strategy implemented, students knew the English knowledge learnt at the time when they got the examination and after the examination, the lesson learnt was disappeared. Frustrated, nervous and worry when facing the English sessions, afraid when an 
English teacher asked questions. The strategy implemented was good, as the strategy was challenging, motivating and the atmosphere created was enjoying and not frightening. Teacher place herself to be a moderator, a facilitator that helped students to communicate their problems. It is in line with Karlsen and Ohna (2021) who state that collaborative learning emphasizes teachers to teach with students' complex efforts to attain their competences. in doing this, teachers should be able to encourage students to work collaboratively.

Collaborative learning facilitate teachers to prmote students' insight of what they are being learned. Therefore, students feel sure that the collaborative learning help a lot in facing their social life in the future. It is in accordance with Ainscow and Messiou (2018) who elaborate that teachers should play an important role to promote students' competences through engaging them in meaningful learning activities. Also, according to the current study, learning English should encourage students in more interesting learning activities. Students feel they get good atmosphere in collaborative learning activities.

Traditional method brought the knowledge of English but did not ask the students to use the language that should be communicated (Wang et al., 2021). The Collaborative Learning strategy forced the students to use their past experience and learnt new knowledge which related to the project assigned where students could not avoid it as they have to complete the assignments. Students liked Collaborative Learning model since they became closer to their friends that developed more understanding, tolerance, respect and love among them. Students considered that all the subjects they have to learn should be implemented in the Collaborative learning, having other model would diversify the atmosphere and tough them a new experience.

Students realized that working in a group was not an easy job, but Collaborative Learning adapted them to work in a team to decrease the ego and to socialize with people. Students learnt some characteristics from their friends and its empower their social life. The key to learn English was having a motivation. Collaborative learning was created the motivation automatically and they enjoyed the atmosphere. Students were happy to get the model of Collaborative Learning as the model gave much beneficial and achieved the goal of learning (Heinimaki et al., 2021). From the result of the evaluation above, the classroom of action research by using a collaborative learning might be a good solution for students in improving the quality of teaching learning process and students' motivation.

\section{CONCLUSION}

Collaborative learning is a strategy of teaching and learning by grouping students to work together to solve a problem, complete an assignment, and produce a product. It increases learners' motivation and promotes a harmonious atmosphere, decreasing classroom anxiety and facilitating interaction discussion and an individual sense of self-centeredness. At the same time, it enlarges students' knowledge and skills. One of the important skills in collaborative learning is oral communication. Oral communication is an important skill to learn as it could express ideas and opinions. It uses to discuss knowledge and bridge the communication for ones who do not understand English. The result of the research stated that because of the atmosphere created was enjoyable, students had feeling of aware to complete the project assignments. Creativeness, responsibility, tolerance, appreciation appeared automatically. It was coming from the happiness and responsibility arisen. Students are happily and actively involved in the discussion. The management's time and responsibility are created well. Students' skills and knowledge are also improved well. Students retained more data from thoughtful discussion and a more positive perspective regarding learning by working together. 


\section{REFERENCES}

Abe, E. (2013). Communicative language teaching in Japan: Current practices and future prospects. English Today, 29(2), 46-53. https://doi.org/10.1017/S0266078413000163

Ainscow, M., \& Messiou, K. (2018). Engaging with the views of students to promote inclusion in education. Journal of Educational Change, 19(1), 1-17. https://doi.org/10.1007/s10833-017-9312-1

Anwar, I. W., Jee, M. J., Adam, S., \& Sailuddin, S. (2021). Willingness to communicate and its influencing factors among Indonesian pre-service teachers. Journal of Languages and Language Teaching, 9(4), 385. https://doi.org/10.33394/jollt.v9i4.4201

Bracken, C. C., \& Lombard, M. (2004). Social Presence and Children: Praise, Intrinsic Motivation, and Learning with Computers. Journal of Communication, 54(1), 22-37. https://doi.org/10.1111/j.1460-2466.2004.tb02611.x

Carvalho, A. R., \& Santos, C. (2021). Developing peer mentors' collaborative and metacognitive skills with a technology-enhanced peer learning program. Computers and Education Open, 100070. https://doi.org/10.1016/j.caeo.2021.100070

Cullen, R., Kullman, J., \& Wild, C. (2013). Online collaborative learning on an ESL teacher education programme. ELT Journal, 67(4), 425-434. https://doi.org/10.1093/elt/cct032

Csizer, K., \& Kormos, J. (2009). Modelling the Role of Inter-Cultural Contact in the Motivation of Learning English as a Foreign Language. Applied Linguistics, 30(2), 166-185. https://doi.org/10.1093/applin/amn025

Deng, Y., Mueller, M., Rogers, C., \& Olechowski, A. (2021). The multi-user computer-aided design collaborative learning framework. Advanced Engineering Informatics, 51, 101446. https://doi.org/10.1016/j.aei.2021.101446

Den Hertog, K., \& Elstak, P. (2020). A collaborative learning network of cities. European Journal of Public Health, 30(Supplement_5), ckaa165.519. https://doi.org/10.1093/eurpub/ckaa165.519

Dong, Y., Yin, H., Du, S., \& Wang, A. (2021). The effects of flipped classroom characterized by situational and collaborative learning in a community nursing course: A quasiexperimental design. Nurse Education Today, 105, 105037. https://doi.org/10.1016/j.nedt.2021.105037

Fehér, J. (2007). Creativity in the Classroom, Pilgrims, UK, Retrieved 30 December 2016.

Fernández-Dobao, A. (2020). Collaborative writing in mixed classes: What do heritage and second language learners think? Foreign Language Annals, 53(1), 48-68. https://doi.org/10.1111/flan.12446

Gokhale, A. A. (1995). "Collaborative learning enhances critical thinking". Journal of Technology Education.

Grunert, J (1997). The course syllabus: A learning-centered approach. Bolton, MA: Anker Publishing.

Haryanti, D. U., Indah, R. N., \& Wahyuni, S. (2021). Enhancing oral proficiency using three steps interview technique for eleventh graders. Journal of Languages and Language Teaching, 9(1), 61. https://doi.org/10.33394/jollt.v9i1.3271

Heinimäki, O.-P., Volet, S., Jones, C., Laakkonen, E., \& Vauras, M. (2021). Student participatory role profiles in collaborative science learning: Relation of within-group configurations of role profiles and achievement. Learning, Culture and Social Interaction, 30, 100539. https://doi.org/10.1016/j.lcsi.2021.100539

Henry, A., \& Cliffordson, C. (2017). The Impact of Out-of-School Factors on Motivation to Learn English: Self-discrepancies, Beliefs, and Experiences of Self-authenticity. Applied Linguistics, 38(5), 713-736. https://doi.org/10.1093/applin/amv060 
Karlsen, A. M. F., \& Ohna, S. E. (2021). Pupils' voices in teachers' collaborative professional learning in Lesson Study. International Journal of Educational Research, 110, 101877. https://doi.org/10.1016/j.ijer.2021.101877

Khonamri, F., Sangari, M., \& Yaqubi, B. (2021). Enhancing EFL learners' quality of interaction through ground rules incorporated in collaborative strategic reading. Journal $\begin{array}{llll}\text { of Languages and Language } 279 . & \text { Teaching, }\end{array}$ https://doi.org/10.33394/jollt.v9i3.3745

Li, A., Zheng, C., Zhang, L., \& Li, X. (2021). Glance and gaze: A collaborative learning framework for single-channel speech enhancement. Applied Acoustics, 187, 108499. https://doi.org/10.1016/j.apacoust.2021.108499

Muñoz-Carril, P.-C., Hernández-Sellés, N., Fuentes-Abeledo, E.-J., \& González-Sanmamed, M. (2021). Factors influencing students' perceived impact of learning and satisfaction in Computer Supported Collaborative Learning. Computers \& Education, 174, 104310. https://doi.org/10.1016/j.compedu.2021.104310

Panitz, T. (1999). Benefits of Cooperative Learning in Relation to Student Motivation", in Theall, M. (Ed.) Motivation from within: Approaches for encouraging faculty and students to excel, New directions for teaching and learning. San Francisco, CA; USA. Josey-Bass publishing.

Sheth, M., Samreen, N., Rapoport, I., Slanetz, P. J., Fornari, A., \& Lewis, P. (2020). Harnessing the Power of Low-tech Collaborative Learning. Journal of Breast Imaging, 2(6), 609-614. https://doi.org/10.1093/jbi/wbaa054

Suparlan, S. (2021). Factors contributing students' speaking anxiety. Journal of Languages and Language Teaching, 9(2), 160. https://doi.org/10.33394/jollt.v9i2.3321

Taguchi, N., \& Kim, Y. (2016). Collaborative Dialogue in Learning Pragmatics: PragmaticRelated Episodes as an Opportunity for Learning Request-Making. Applied Linguistics, 37(3), 416-437. https://doi.org/10.1093/applin/amu039

Uztosun, M. S. (2020). The development of a scale for measuring the self-regulated motivation for improving speaking English as a foreign language. Language Learning Journal, 48(2), 213-225. https://doi.org/10.1080/09571736.2017.1335766

Van de Guchte, M., Rijlaarsdam, G., Braaksma, M., \& Bimmel, P. (2019). Focus on language versus content in the pre-task: Effects of guided peer-video model observations on task performance. Language Teaching Research, 23(3), 310-329. https://doi.org/10.1177/1362168817735543

Wang, G., Yin, J., Hossain, M. S., \& Muhammad, G. (2021). Incentive mechanism for collaborative distributed learning in Artificial Intelligence of Things. Future Generation Computer Systems, 125, 376-384. https://doi.org/10.1016/j.future.2021.06.015 